\title{
KONTRIBUSI TINGKAT RELIGIUSITAS DAN PROMOSI TERHADAP MINAT MASYARAKAT MENJADI NASABAH TABUNGAN
}

\author{
Resky Ardiansyah $^{1)^{*}}$ Herman Sjahruddin $^{2)}$ Orfiyanni S Themba ${ }^{2)}$ Andi Tenriola $^{2)}$ \\ 1) Manajemen Perbankan, Sekolah Tinggi Ilmu Ekonomi Makassar Bongaya, Makassar, Sulawesi Selatan \\ 2) Sekolah Tinggi Ilmu Ekonomi Makassar Bongaya, Makassar, Sulawesi Selatan \\ *Penulis korespondensi: reskyardian150@gmail.com
}

\begin{abstract}
Penelitian ini bertujuan untuk menguji kontribusi tingkat religiusitas dan promosi terhadap minat masyarakat menjadi nasabah. Populasi dalam penelitian ini adalah Nasabah PT. Bank BNI Syariah (Persero) Tbk Cabang Makassar. Jumlah sampel sebanyak 49 yang diperoleh dengan menggunakan Nonprobability sampling. Untuk mencapai tujuan dalam penelitian ini menggunakan metode analisis regresi linier berganda SPSS Ver. 22. Nilai t-statistik memberikan bukti jika tingkat religiusitas yang dimiliki nasabah dan promosi yang dilakukan pihak manajemen bank terbukti memberikan kontribusi yang positif dan signifikan terhadap peningkatan minat masyarakat menjadi nasabah.
\end{abstract}

Keywords: Religiusitas, promosi, minat nasabah. 


\section{PENDAHULUAN}

Minat adalah kecenderungan seseorang untuk menentukan pilihan aktifitas dan tergantung dari kondisi individu sehingga bersifat labil (Muhaimin 1994). Pernyataan serupa diungkapkan Poerwadarminta (2006), bahwa secara istilah, minat dimaknai sebagai perangkat mental yang terdiri dari suatu campuran dari perasaan, harapan, pendirian, prasangka, atau kecenderungan lain yang mengarahkan individu kepada suatu pilihan tertentu tanpa ada suatu paksaan dari pihak lain (Sunardi dan Fety Aniarsih, 2013). Salah satu upaya yang dibutuhkan dalam mewujudkan pelayanan yang maksimal kepada nasabah, maka karyawan BRI dituntut untuk memaksimalkan kinerja mereka selaku karyawan melalui peningkatan disiplin kerja, pemberian insentif dan tunjangan yang adil dan proporsional. Teori individual performance (Timpe, 1992; dalam Sari dan Cipto, 2018) menegaskan bahwa pencapaian individual dipicu oleh dua konstrain, pertama konstrain internal terkait dengan kepribadian dan motivasi kerja, (tunjangan, insentif dan disiplin kerja) dan sisi personalitas lainnya, kedua yaitu konstrain eksternal yang bersumber pada kepemimpinan dan lingkungan kerja serta aturan organisasi.

Masyarakat berminat untuk menjadi nasabah atau tidak sama sekali dipengaruhi oleh sikap masyarakat terhadap karakteristik dari perbankan tersebut (Uniyanti, 2018). Pernyataan tersebut relevan dengan teori konfirmasi (Ramli dan Sjahruddin, 2015) bahwa nasabah tertarik / berminat untuk menjadi nasabah perbankan disebabkan karena adanya harapan mereka pada saat dilakukannya pra-pembelian, sehingga dengan demikian melakukan penilaian atau evaluasi terhadap jasa dan produk bank yang akan digunakannya, apabila sesuai dengan harapannya maka terjadi konfirmasi atau keinginan untuk menjadi nasabah sebaliknya apabila tidak sesuai dengan harapan mereka, maka terjadi diss-confirmasi atau keengganan menjadi nasabah.

Terdapat beberapa faktor yang mempengaruhi minat nasabah antara lain; religiusitas, pendapatan, informasi produk bank syariah, lokasi (tempat), dan promosi, di antara beberapa faktor tersebut terdapat faktor penting yaitu religiusitas dan promosi (Uniyanti, 2018). Religiusitas merupakan suatu sistem yang kompleks dari kepercayaan, keyakinan, sikap - sikap dan upacara - upacara yang menghubungkan individu dengan satu keberadaan atau kepada sesuatu yang bersifat ketuhanan. Religiusitas adalah suatu kesatuan unsur-unsur yang komprehensif, yang menjadikan seseorang disebut sebagai orang beragama (being religious), dan bukan sekedar mengaku mempunyai agama (having religon). Religiusitas meliputi pengetahuan agama, keyakinan agama, pengalaman ritual agama, pengalaman agama, perilaku (moralitas) agama, dan sikap sosial agama. (Mufti Arsyidian, 2019).

Hasil penelitian terdahulu yang dilakukan oleh Wahyu Utami dkk, (2015) menunjukkan hasil bahwa secara simultan terdapat pengaruh yang positif dan signifikan antara faktor religiusitas, kelompok referensi, dan motivasi, terhadap keputusan masyarakat menjadi nasabah di bank syariah.

Kemudian penelitian yang dilakukan oleh Desy Fatmawati (2015) menunjukkan hasil bahwa religiusitas dan promosi masyarakat tidak berpengaruh terhadap minat masyarakat menjadi nasabah pada bank syariah untuk kalangan santri mahasiswa PP. Wahid Hasyim, Sleman. Hal ini ditunjukkan dengan nilai signifikansi sebesar 0,845 . Sehingga santri yang mempunyai pendapatan (uang saku) dalam kategori sangat rendah hingga sangat tinggi memiliki probabilitas yang sama untuk berintensi menjadi nasabah di bank syariah..

Dari kedua hasil penelitian di atas ditemukan sedikit perbedaan. Hasil penelitian 
pertama menunjukkan bahwa religiusitas mempunyai pengaruh yang signifikan, sedangkan hasil penelitian kedua menunjukkan bahwa religiusitas tidak berpengaruh signifikan. Namun semua faktor-faktor tersebut dipercaya berpengaruh terhadap intensi atau niat masyarakat menjadi nasabah di bank syariah.

Selain faktor religiusitas yang menjadi minat masyarakat menjadi nasabah di Bank Syariah terdapat juga faktor lain yang mempengaruhi yaitu promosi. Promosi merupakan strategi pemasaran yang dilakukan oleh bank kepada nasabah untuk menjelaskan produk-produk bank sehingga nasabah mendapatkan informasi yang jelas mengenai produk yang ditawarkan bank dan nasabah akan memilih produk yang sesuai. (Taufik Saifudin, 2018).

Penelitian Daniel Ortega dan Anas Alhifni (2017) menunjukkan hasil bahwa secara signifikan antar promosi dan minat menjadi nasabah di bank syariah, dengan hasil penelitian yang telah dilakukan terhadap masyarakat menunjukkan bahwa media promosi berpengaruh terhadap minat menjadi nasabah dibank syariah.

Penelitian Olivia Firda Yuanita (2017) yang berjudul bahwa promosi tidak berpengaruh signifikan terhadap keputusan menjadi nasabah, di BMT Mandiri Sejahtera Cabang Pasar Kranji.

Dari kedua hasil penelitian di atas ditemukan sedikit perbedaan. Hasil penelitian pertama menunjukkan bahwa promosi mempunyai pengaruh yang signifikan, sedangkan hasil penelitian kedua menunjukkan bahwa promosi tidak berpengaruh signifikan. Namun semua faktor-faktor tersebut dipercaya berpengaruh terhadap intensi atau niat menjadi nasabah di bank syariah.

Penelitian Taufik Saifudin (2018) menyarakan bahwa promosi dan religiusitas berpengaruh positif dan signifikan terhadap minat menjadi nasabah masyarakat Kota Salatiga di Bank Syariah.
Tabel 1. Perkembangan Nasabah PT Bank BNI Syariah Kantor Cabang Makassar

\begin{tabular}{|c|c|}
\hline Tahun & Jumlah Nasabah \\
\hline 2017 & 3.679 \\
\hline 2018 & 5.630 \\
\hline 2019 & 8.211 \\
\hline
\end{tabular}

Tabel 1 menunjukkan jumlah nasabah yang mengalami peningkatan yang sangat pesat pada rentang waktu 2018 - 2019 menjadi salah satu alasan dilakukannya penelitian ini, selain itu peneliti juga ingin menguji apakah peningkatan nasabah tersebut diakibatkan karena faktor tingkat religiusitas masyarakat dan promosi yang baik menjadi penyebab meningkatnya ketertarikan masyarakat untuk menjadi nasabah tabungan pada PT Bank BNI Syariah Kantor Cabang Makassar.

\section{TINJAUAN PUSTAKA}

\section{Konsep Perbankan Syariah}

Bank Syariah adalah bank yang beroperasi dengan tidak mengandalkan pada bunga. Bunga adalah tanggungan pada pinjaman uang, yang biasanya dinyatakan dalam presentase dari uang yang dipinjamkan. Bank Syariah adalah lembaga keuangan yang operasional dan produknya dikembangkan berlandaskan pada alquran dan hadits nabi SAW atau dengan kata lain bank syariah adalah lembaga keuangan yang usaha pokoknya memberikan pembiayaan dan jasajasa lainnya dalam lalu lintas pembayaran serta peredaran uang yang pengoperasiannya disesuaikan dengan prinsip syariat islam ( Muhammad, 2011).

\section{Konsep Religiusitas}

Religiusitas merupakan suatu sistem yang kompleks dari kepercayaan, keyakinan, sikap - sikap dan upacara - upacara yang menghubungkan individu dengan satu keberadaan atau kepada sesuatu yang bersifat ketuhanan. Religiusitas adalah suatu kesatuan unsur-unsur yang komprehensif, yang menjadikan seseorang disebut sebagai orang beragama (being religious), dan bukan sekedar 
mengaku mempunyai agama (having religon). Religiusitas meliputi pengetahuan agama, keyakinan agama, pengalaman ritual agama, pengalaman agama, perilaku (moralitas) agama, dan sikap sosial agama. (Mufti Arsyidian, 2019). Pengukuran yang dapat digunakan dalam pemberian religiusitas terdiri dari dua jenis (Mufti Arsyidian, 2019) yaitu : pengetahuan, keyakinan agama, pengalaman agama, moralitas, dan sikap sosial agama.

\section{Konsep Promosi}

Menurut (Lupiyoadi, 2006), promosi merupakan strategi pemasaran yang dilakukan oleh bank kepada nasabah untuk menjelaskan produk-produk bank sehingga nasabah mendapatkan informasi yang jelas mengenai produk yang ditawarkan bank dan nasabah akan memilih produk yang sesuai.

Pengukuran yang dapat digunakan dalam pemberian promosi terdiri dari dua jenis (Hamdani, 2016). yaitu periklanan, promosi penjualan, hubungan masyarakat, penjualan perseorangan, dan penjualan lansung.

\section{Konsep Minat}

Minat adalah suatu rasa atau proses ketertarikan yang dirasakan seseorang terhadap suatu produk, dan ingin mencoba, menggunakan atau mungkin memiliki produk tersebut. Pengertiann minat menabung adalah suatu rasa ketertarikan yang diarsakan oleh seseorang terhadap suatu produk perbankan, dan ingin mencoba, menggunakan dan memiliki produk tersebut dalam hal tabungan. (Doni Marlius, 2016). Indikator Minat yaitu minat transaksional, minat rerensial, minat prefensial,

\section{METODE PENELITIAN}

Pendekatan penelitian kuantitatif digunakan dengan penalaran deduktif kuantitatif yang dipakai dalam menganlisis populasi atau sampel dengan penarikan sampel secara total sampling (Sugiyono, 2017 : 23). Populasi sekaligus bertindak sebagai sampel pada riset ini adalah nasabah PT. Bank BNI Syariah (Persero) Tbk Cabang Makassar, yang berjumlah 49 (empat puluh sembilan) .

\section{DEFENISI OPERASIONAL}

1) Religiusitas merupakan suatu sistem yang kompleks dari kepercayaan, keyakinan, sikap - sikap dan upacara - upacara yang menghubungkan individu dengan satu keberadaan atau kepada sesuatu yang bersifat ketuhanan. Religiusitas adalah suatu kesatuan unsur-unsur yang komprehensif, yang menjadikan seseorang disebut sebagai orang beragama (being religious), dan bukan sekedar mengaku mempunyai agama (having religon)

2) Promosi merupakan strategi pemasaran yang dilakukan oleh bank kepada nasabah untuk menjelaskan produk-produk bank sehingga nasabah mendapatkan informasi yang jelas mengenai produk yang ditawarkan bank dan nasabah akan memilih produk yang sesuai.

3) Minat adalah suatu rasa atau proses ketertarikan yang dirasakan seseorang terhadap suatu produk, dan ingin mencoba, menggunakan atau mungkin memiliki produk tersebut.

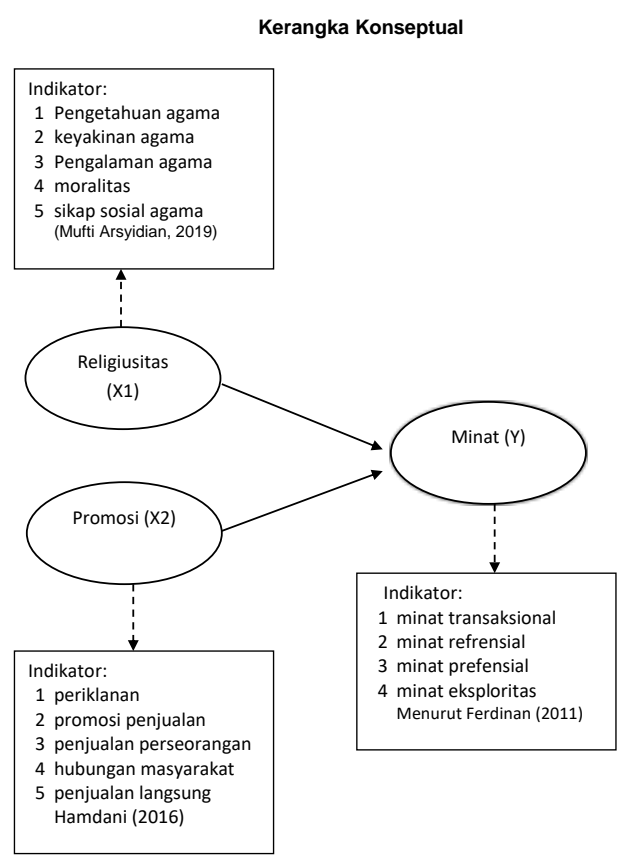

Gambar 1, Kerangka Konseptual

Kerangka konsep tersebut menggambarkan keterkaitan antara religiusitas dan promosi dengan minat nasabah.

\section{METODE ANALISIS}

1. Deskriptif statistik merupakan profile data yang membandingkan nilai rerata antara konstruk. 
2. Analisis Statistik Inferensial digunakan untuk menganalisis data sampel dengan menggunakan analisis regresi berganda (multiple regression method) yang bertujuan untuk mempelajari hubungan antara variabel yaitu hubungan antara variabel independen $(\mathrm{X})$ dengan variabel dependen (Y). Persamaan regresi linear berganda adalah sebagai berikut:

$$
\mathbf{Y}=\alpha+\boldsymbol{\beta}_{1} \mathbf{X}_{1}+\boldsymbol{\beta}_{2} \mathbf{X}_{2}+\boldsymbol{\beta}_{3} \mathbf{X}_{3}+\mathrm{e}
$$

Penggunaan analisis regresi melalui beberapa tahapan (Ghozali, 2016:52; Umar,2010:194), yaitu :

\section{a. Uji Instrumen}

1) Validitas, kesahihan atau tidaknya instrument riset.

2) Reliabilitas, kemampuan indikator dalam menjelaskan variabel pengamatan.

\section{b. Uji Asumsi Klasik}

Pengujian asumsi regresi menggunakan beberapa pengujian, yaitu; normalitas, autokorelasi, multikolinearitas, heterokedastisitas, dan linieritas.

\section{c. Pengujian model regresi}

$\begin{array}{ccc}\text { Uji-F } & \text { (goodness of fit test) } \\ \text { digunakan } & \text { untuk } & \text { mengetahui }\end{array}$ kelayakan model regresi linear berganda sebagai alat analisis yang menguji pengaruh antar variabel

\section{d. Uji Hipotesis}

1) Uji $-t$, digunakan untuk menguji koefisien secara parsial adalah untuk mengetahui pengaruh antar variabel.

2) Uji koefisien determinasi $\left(R^{2}\right)$, digunakan untuk mengukur kontribusi variabel bebas (Ghozali, 2013: 87).

\section{HASIL DAN PEMBAHASAN}

\section{A. Karakteristik Responden}

Responden penelitian ini sebanyak 49 responden. Hasil pada deskripsi jenis kelamin, diketahui bahwa sebagian besar karyawan berjenis kelamin Pria sebesar 28 orang atau57.1\%. Sedangkan sisanya responden Wanita berjumlah 21 orang atau
42.9\%. Berdasarkan karakteristik berdasarkan pekerjaan yaitu PNS/Karyawan sebanyak 19 orang dengan tingkat persentasi $38.8 \%$, TNI/POLRI sebanyak 20 orang dengan tingkat persentase $40.8 \%$, sedangkan WIRASWASTA sebanyak 10 orang dengan tingkat persentase $20.4 \%$ orang.

Karakteristik responden tingkat pendidikan yaitu SMA sebanyak 11 orang dengan tingkat persentase $22.4 \%$, SARJANA sebanyak 34 orang dengan tingkat persentase $69.4 \%$, sedangkan tingkat pendidikan MAGISTER sebanyak 4 orang dengan tingkat pesentase $8.2 \%$.

Karakteristik Lama menjadi nasabah yaitu 1-2 tahun sebanyak 18 orang dengan tingkat persentase $36.7,3-4$ tahun sebanyak 17 orang dengan tingkat persentase $34.7 \%$, dan $>4$ tahun sebanyak 14 orang dengan tingkat persentase $28.6 \%$.

Penjabaran terhadap analisis data terhadap deskriptif responden pada penelitian ini dapat ditujuan sebagai tabel berikut:

\section{Tabel 2. Karakteristik Responden}

\begin{tabular}{lccc}
\hline \multicolumn{1}{c}{ Uraian } & & $\begin{array}{c}\text { Jumla } \\
\mathrm{h}\end{array}$ & $\begin{array}{c}\text { Persenta } \\
\text { si }\end{array}$ \\
\hline Jumlah Sampel & & 70 & $100 \%$ \\
\hline Distribusi Kuesioner & & 70 & $100 \%$ \\
\hline $\begin{array}{l}\text { Kuesioner } \\
\text { Dikembalikan }\end{array}$ & Yang & 49 & $70 \%$ \\
\hline $\begin{array}{l}\text { Kuesioner } \\
\text { Rusak/Cacat }\end{array}$ & Yang & 21 & $30 \%$ \\
\hline $\begin{array}{l}\text { Kuesioner Yang } \\
\text { Diuji }\end{array}$ & Layak & 49 & $70 \%$ \\
\hline
\end{tabular}

Tingkat pengembalian instrumen penelitian sebesar $70 \%$, hal ini disebabkan karena adanya responden yang tidak mengisi secara lengkap tanggapan mereka.

\section{B. Uji Instrumen}

Uji Validitas, keseluruhan item mempunyai nilai correlation $>0.30$ dan signifikan $<0.05$ sehingga dengan demikian item memiliki validitas yang layak dan signifikan. Uji Reabilitas, nilai cronbach's $a l p h a$, semuanya menunjukkan $=>0.60$. 


\section{Uji Penyimpangan Regresi}

Pemanfaatan regresi mensyaratkan data harus memenuhi unsur best, linear, unbiassed dan linearitas. Untuk itu pengujiannya ditunjukkan sebagai berikut:

Tabel 3. Kenormalan Data

\begin{tabular}{cc}
\hline Pengukuran & Nilai $>\mathbf{0 . 0 5}$ \\
\hline t-statistik & 0.092 \\
\hline p-value & 0.200
\end{tabular}

Data Diolah, 2020

Nilai K-S $=0.092>0.05$ dan nilai $\mathrm{p}$ value $=0.200>0.05$, hasil tersebut menunjukkan bahwa pengujian memenuhi kenormalan data.

Fakta tersebut dibuktikan dengan pengujia P-P plot seperti pada gambar berikut ini:

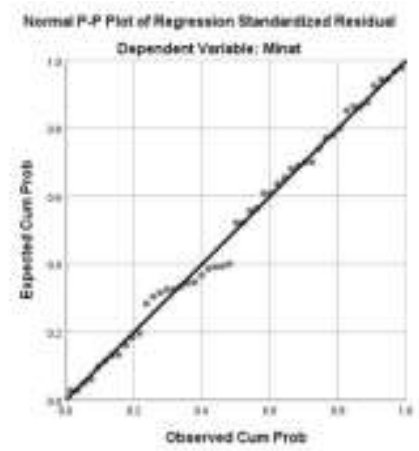

Gambar 2. P-P Plot

Gambar 2 membuktikan bahwa titik-titik berdistribusi pada garis diagonal dan penyebarannya searah dengan garis tersebut.

Tabel 4. Multikol Data

\begin{tabular}{lll}
\hline Pengukur & Tol. & VIF \\
\hline Religiusitas & 0.833 & 1.201 \\
\hline Promosi & 0.833 & 1.201 \\
\hline
\end{tabular}

Nilai Tolerance untuk masing-masing variabel lebih kecil dari 1 dan nilai VIF lebih kecil dari 10, dengan demikian maka tidak terjadi gangguan data yang kompleks pada penelitian ini.

Tabel 5. Gangguan Hubungan Data

\begin{tabular}{ccc}
$\begin{array}{c}\text { Durbin upper } \\
(\mathrm{du})\end{array}$ & $\begin{array}{c}\text { Durbin } \\
\text { watson }\end{array}$ & $\begin{array}{c}\text { Durbin lower } \\
(\mathrm{dl})\end{array}$ \\
\hline
\end{tabular}
1.6257
2.343
1.4563

Nilai Durbin Watson $=2.343$ terletak diantara batas Durbin Upper (dU) 1.6257 dan Durbin lower (4-dU) 2.3743. Maka gangguan hubungan data sama dengan nol, berarti tidak ada autokorelasi.

Tabel 6. Uji Heterokedastisitas

\begin{tabular}{|l|l|l|}
\hline Variabel & t-statistik & p-value \\
\hline Konstanta & 1.157 & 0.253 \\
\hline Religiusitas & 1.059 & 0.295 \\
\hline Promosi & 0.821 & 0.416 \\
\hline
\end{tabular}

Religiusitas memiliki nilai sig $0.295>$ 0,05 , dan variabel promosi memiliki nilai sig $0,416>0,05$. Dari hasil tersebut dapat disimpulkan bahwa variabel yang di uji tidak terjadi heterokedastisitas, sehingga model regresi yang dilakukan layak dipakai.

\section{Pembahasan}

Penjelasan terhadap analisis data dalam pengajuan hipotesa, dapat ditunjukkan sebagai berikut:

Tabel 7. Deskriptif Statistik

\begin{tabular}{|l|l|l|}
\hline Variabel & Rata-Rata & Stand.Deviasi \\
\hline Minat & 3.4602 & .35789 \\
\hline Religiusitas & 3.6900 & .30094 \\
\hline Promosi & 3.5678 & .36587 \\
\hline
\end{tabular}

Secara rata-rata keseluruhan tanggapan responden > nilai standar deviasi. Pengujian parsial yang digunakan dalam regresi dapat ditunjukkan sebagai berikut:

Tabel 8. Uji Parsial

\begin{tabular}{|l|l|l|l|}
\hline Model & Beta & t-stat & $\mathrm{p}$-value \\
\hline (Constant) &, 614 & 1.208 & .233 \\
\hline Religiusitas &, 197 & 1.418 & .163 \\
\hline Promosi &, 594 & 5.206 & .000 \\
\hline
\end{tabular}


Formulasi regresi dapat dituliskan:

$\mathrm{Y}=0.614+0.165+0.607+0.509$

Dari persamaan regresi tersebut, dapat dijelaskan sebagai berikut:

a. Nilai konstanta sebesar 0.614 menunjukkan jika tinkat religiusitas dan promosi $=0$, maka minat nasabah mengalami kenaikan 0.614

b. Koefisien regresi religiusitas sebesar 0,165 yang bernilai positif mencerminkan jika religiusitas meningkat sebesar satu satuan, maka minat nasabah mengalami kenaikan sebesar 0,165.

c. Koefisien regresi promosi sebesar 0,607 dan menunjukkan hasil yang positif mencerminkan jika promosi meningkat sebesar satu satuan, maka minat nasabah mengalami kenaikan sebesar 0,607 sehingga dapat dinyatakan jika promosi yang dilakukan perbankan dengan baik merupakan upaya perbankan untuk menarik minat masyarakat untuk menjadi nasabah.

\section{Hasil Uji Hipotesis}

Berdasarkan tabel diatas variabel Religiusitas menunjukkan $\mathrm{T}_{\text {hitung }}$ sebesar 1.418 sementara itu nilai $\mathrm{T}_{\text {tabel }}=2.012$, maka $\mathrm{T}_{\text {hitung }}<$ $\mathrm{T}_{\text {tabel }}$ dan nilai signifikansi yaitu $0.163>0.05$ oleh karna itu dapat disimpulkan bahwa Religiusitas $\left(\mathrm{X}_{1}\right)$ berpengaruh positif dan tidak signifikan terhadap minat nasabah $(\mathrm{Y})$.

Sedangkan untuk variabel Promosi memiliki nilai $\mathrm{T}_{\text {hitung }}=5.206$ dan nilai $\mathrm{T}_{\text {tabel }}=$ 2.012, maka nilai $\mathrm{T}_{\text {hitung }}>\mathrm{T}_{\text {tabel }}$ dan nilai signifikansi yaitu $0.000<0.05$ artinya promosi $\left(\mathrm{X}_{2}\right)$ berpengaruh positif dan signifikan terhadap minat nasabah.
Tabel 9. Pengujian Variabel Dominan

\begin{tabular}{|l|c|c|c|}
\hline $\begin{array}{l}\text { Pearson } \\
\text { norrealatio }\end{array}$ & $\begin{array}{c}\text { Mina } \\
\text { t }\end{array}$ & $\begin{array}{c}\text { Religiusuta } \\
\text { s }\end{array}$ & $\begin{array}{c}\text { Promos } \\
\mathbf{i}\end{array}$ \\
\hline Minat & - & 0.414 & 0.675 \\
\hline Religiusitas & 0.414 & - & 0.409 \\
\hline Promosi & 0.675 & 0.409 & - \\
\hline
\end{tabular}

Berdasarkan tabel 8, dapat disimpulkan bahwa pengaruh dominan yang diperoleh dari nilai pearson correlation dengan nilai Standardized Coefficients yang dapat dijelaskan dibawah ini yaitu sebagaib berikut: Kontribusi $\mathrm{X}_{1}$ sebesar 6.83\% $=0.414$ X 0,165 Kontribusi $\mathrm{X}_{2}$ sebesar $40.97 \%=0.675$ X 0,607

Berdasarkan penjelasan tersebut, diperoleh pengaruh dominan dari nilai variabel ( $\left.\mathrm{X}_{2}\right)$ 40,97\% lebih besar dibandingkan variabel $\left(\mathrm{X}_{1}\right)$ yaitu sebesar 6,83\%. maka dapat disimpulkan variabel promosi berpengaruh dominan terhadap minat.

Berdasarkan penjelasan tersebut, dapat juga dijelaskan pengujian koefisien determinasi yang dilandasi dari nilai kontribusi $6.83 \%$ dari variabel (X1) dan $40.97 \%$ dari variabel (X2) dengan total berjumlah $47.90 \%$ atas semua kontribusi varaibel bebas yang diteliti terhadap variabel terikat. Hal ini dapat dijelaskan pada pengujian yang dilakukan dibawah yaitu sebagai berikut:

Table 10. Koefisien Determinasi $\left(\mathbf{R}^{2}\right)$

\begin{tabular}{|c|l|c|l|}
\hline \multicolumn{4}{|c|}{ Model Summary $^{\mathbf{b}}$} \\
\hline Model & R & R Square & $\begin{array}{l}\text { Adjusted R } \\
\text { Square }\end{array}$ \\
\hline 1 & $.692^{\mathrm{a}}$ & 0.479 & 0.456 \\
\hline
\end{tabular}

Sehingga pengaruh variabel bebas (Independen) yaitu religiusitas dan promosi terhadap variabel terikat (Dependen) yaitu minat nasabah sebesar $47.90 \%$, sedangkan sisanya sebesar $52.10 \%$ dipengaruhi oleh faktor lain yang tidak dijelaskan dalam penelitian ini. 


\section{Interpretasi Hasil Penelitian}

\section{a. Pengaruh Religiusitas terhadap Minat Nasabah}

Religiusitas berpengaruh positif terhadap Minat Nasabah. Analisis uji-t untuk variabel religiusitas, nilai t-hitung sebesar 1.418, sementara itu nilai t-tabel sebesar 2.012 maka t-hitung < t-tabel dan nilai signifikansi yaitu $0,163>0,05$ maka individual religiusitas berpengaruh positif tidak bermakna terhadap minat nasabah. Temuan tersebut menjelaskan jika ketertarikan untuk menjadi nasabah tidak disebabkan karena tingkat religiusitas yang dimiliki nasabah,

Temuan ini berbeda dengan hasil penelitian Wahyu Utami dkk, (2015) bahwa terdapat pengaruh yang positif dan signifikan antara faktor religiusitas terhadap keputusan masyarakat menjadi nasabah di bank syariah. Relevansi temuan ditunjukkan pada sudi yang dilakukan Desy Fatmawati (2015) bahwa religiusitas bukan menjadi pemicu minat masyarakat menjadi nasabah pada bank syariah.

\section{b. Pengaruh Promosi terhadap Minat Nasabah}

Promosi berpengaruh positif terhadap Minat Nasabah. Analisis uji-t untuk variabel religiusitas, nilai t-hitung $=5.206$, sementara itu nilai t-tabel $=2.012$, sehingga hasil tersebut menjelaskan t-hitung $>\mathrm{t}$-tabel dengan $\mathrm{p}$-value $=0,000<0,05$ maka dapat dijelaskan jika promosi berpengaruh positif dan signifikan terhadap minat nasabah.

Temuan ini mendukung hasil penelitian yang Yasir Zahri dan Hafasnuddin (2016); Sjahruddin, H., \& Akbar, S. (2020); Wirawan, A. A., Sjahruddin, H., \& Razak, N. (2019). bahwa secara parsial variabel promosi berpengaruh signifikan terhadap minat nasabah.

\section{c. Pengaruh Religiusitas dan Promosi terhadap Minat Nasabah}

Berdasarkan hasil analisis uji koefisien korelasi, diperoleh pengaruh dominan dari nilai variabel $\left(\mathrm{X}_{2}\right) \quad 40.97 \%$ lebih besar dibandingkan variabel $\left(\mathrm{X}_{1}\right)$ yaitu sebesar 6.83\%. maka dapat disimpulkan variabel Promosi berpengaruh dominan terhadap minat nasabah.

\section{KESIMPULAN DAN SARAN \\ Kesimpulan}

Religiusitas berpengaruh positif namun tidak bermakna dalam meningkatkan minat nasabah, ketertarikan untuk menjadi nasabah bukan disebabkan karena persoalan keyakinan dan keimanan semata namun dalam penelitian ini disebabkan karena promosi yang dilakukan perbankan syariah.

Promosi berpengaruh positif dan signifkan terhadap minat nasabah. artinya promosi adalah sebagai sarana yang mengimpormasikan kepada calon pembeli sehingga dapat menarik minat masyarakat untuk menjadi nasabah. Sehingga dengan hasil tersebut menunjukkan jika kontribusi dominan ditunjukkan melalui promosi

Saran

Promosi yang dilakukan telah menunjukkan hasil yang nyata sehingga direkomendasikan kepada perbankan syariah untuk mempertahankan, bahkan dilakukan peningkatan promosi sehingga perbankan syariah dapat bersaing dengan bank konvensional.

Kepada peneliti lanjutan diharapkan mengeksplorasi lebih jauh tingkat religiuisitas karena pada studi ini belum diperoleh hasil yang bermakna

\section{REFERENSI}

Arsyidian, Mufti. (2019). Pengaruh Persepsi, Tingkat Religiusitas dan Disposable Income Terhadap Minat Masyarakat 
Menjadi Nasabah di Perbankan Syariah. Skripsi. Jurusan Perbankan Syariah Universitas Islam Negeri Walisongo Semarang.

Ali Muhson. (2012). Materi Pelatihan Analisis

Statistik dengan SPSS. Fakultas

Ekonomi Universitas Negeri

Yogyakarta.

Dayyan. Muhammad., Fahriansah, Juprianto. (2017). Analisis Minat Masyarakat Muslim Menjadi Nasabah Bank Syariah (Studi Kasus di Gampong Pondok Kemuning). Fakultas Ekonomi dan Bisnis Islam IAIN Langsa. Jurnal Ilmiah Mahasiswa (JIM). Vol.1 No.1.

Doni Marlius. (2016), Pengaruh Bauran Pemasaran Jas Terhadap Minat Masyarakat Dalam Menjadi Nasabah Pada Bank Nagari Cabang Muaralabuh, Jurmal. Vol. 03 (01), April 15.

Indriyo, Gitosudarmo. (2000). Manajemen Pemasaran edisi pertama. Yogyakarta: BPFE.

Kasmir. (2012). Dasar-Dasar Perbankan. Jakarta: PT. Raja Grafindo Persada.

Lucas,D.B. dan Britt, (1950). Advertising Psycology and Research, New York: McGraw-Hill

Maghfiroh, Sayyidatul. (2018). Pengaruh Religiusitas, Pendapatan dan Lingkungan Sosial Terhadap Minat Masyarakat Menjadi Nasabah di Bank Syariah Pada Santri Pesantren Mahasiswi Darush Salihat. Skripsi. Program Studi Pendidikan Ekonomi Universitas Negeri Yogyakarta.

Mangani, Ktut Silvanita. (2009). Bank dan Lembaga Keuangan Lain. Jakarta: PT Gelora Aksara Pratama.

Muhammad (2011). Manajemen Bank Syariah, Yogyakarta: Sekolah Tinggi Ilmu Manajemen YKPN

Ningsih, Sri Ningsih. (2017). Pengaruh Persepsi, Tingkat Religiusitas dan Disposable Income Terhadap Minat Masyarakat Menjadi Nasabah di
Perbankan Syariah (Studi Pada Dosen UIN Raden Intan Lampung).

Olivia Firda Yuanita. (2017). Pengaruh Produk Kualitas Jasa, Promosi dan Lokasi Terhadap Keputusan Menjadi Nasabah (Studi pada BMT Mandiri Sejahtera Cabang Pasar Kranji, Lamongan, Jawa Timur). Faukultas.

Sjahruddin, H., \& Akbar, S. (2020). Dampak Promosi, Harga, Dan Diferensiasi Produk Dalam Meningkatkan Keputusan Pembelian. Jurnal Administrasi dan Manajemen, 10(2), 172-179.

Wirawan, A. A., Sjahruddin, H., \& Razak, N. (2019). Pengaruh Kualitas Produk dan Lokasi Terhadap Loyalitas Pelanggan Melalui Kepuasan Pelanggan Sebagai Variabel Intervening Pada Lamuna Coffee di Kabupaten Bone. 